\section{РАЗРАБОТКА СИМВОЛЬНОГО ОБРАЗА СТРОИТЕЛЬНОГО} СООРУЖЕНИЯ В САПР

Показано, что автоматизированное строительное проектирование постоянно требует обновления модели сооружения Эта модель должна отражать не только первичное техническое задание на строение, но и выявленные при проектировании изменения и события в турбулентной внутренней и внешней окружающей будущее строительство среде. Предложена модель строительного сооружения в виде символьного образа комплексной генетической хромосомы и метод поддержки адекватности между ним и переменной средой.

Ключевые слова: строительное проектирование, обновление модели, турбулентная среда, символьный образ, техническая наследственность.

Stanovskyi Alexandr, Doctor of Technical Science, Professor, De partment of Oilgas and Chemical Mechanical Engineering, Odessa
National Polytechnic University, Ukraine, ORCID: http://orcid.org/ 0000-0002-0360-1173

Abu Shena Osama, Department of Oilgas and Chemical Mechanical Engineering, Odessa National Polytechnic University, Ukraine, e-mail: abu.shena@gmail.com,ORCID: https://orcid.org/0000-00032722-7638

Toropenko Oleksii, Department of Oilgas and Chemical Mechanical Engineering, Odessa National Polytechnic University, Ukraine, e-mail: alexey.toropenko@geomoras.net, ORCID: https://orcid.org/ 0000-0002-3699-4460

Daderko Olesya, Department of Oilgas and Chemical Mechanical Engineering, Odessa National Polytechnic University, Ukraine, e-mail: o.daderko@gmail.com,ORCID: https://orcid.org/0000-00030160-7288

\section{Antypenko Y., Ivko $A$.}

\title{
ANALYSIS OF APPROACHES TO DEVELOP OF THE COMPETENTS SYSTEM OF THE PROJECT TEAM OF THE BUILDING COMPANY VIRTUAL LOGISTIC CENTER CREATION
}

Поставлена задача розвитку компетентності проекту створення віртуального логістичного центру будівельної компанії. Досліджено підходи до ідентифікащії і розвитку індивідуальної i організаційної компетентності. Для проекту розглянуто наповнення 28-и компетенцій згідно з моделлю Міжнародної асоціації управління проектами. Запропонована комбінована модель розвитку організаційно-індивідуальних компетенцій.

Ключові слова: управління проектами, будівельна логістика, компетентність проекту, організаційно-індивідуальні компетенції.

\section{Introduction}

The trend in modern management has become the use of virtual organizational structures and virtual project teams. This trend is relevant for the construction sphere. More and more companies are thinking about minimizing the costs of maintaining offices and moving to the remote form of managing employees.

This approach is especially relevant in construction logistics. This construction specialization requires constant territorial dynamics of logistics, permanent and all-round contacts, including eye and personal contacts, including with stakeholders, territorially distributed in the space of a city or region.

In this sense, construction companies should consider the virtual approach as the basis for organizing teams and teams of construction logistics. To start such association, which can be called a virtual logistics center for construction, it is necessary to carry out activities that are of a project nature. Namely, to implement the pro- ject of creating a virtual logistics center of a construction company.

However, this project has certain risks associated with the issue of ensuring the necessary discipline of the virtual project team members, the performance of tasks assigned to them on time and qualitatively. This requires the formation of approaches to development of the competence system of the team of such project.

\section{The object of research and its technological audit}

The object of research is the system of competence of the team creating a virtual logistics center of a construction company.

Technological audit of the object reveals differences in the competence system for projects implemented in various fields of application (applied spheres). Along with the differences, in the systems of competences in different areas there are common features. So, the core of the 
competence system of the team creating a virtual logistics center of a construction company will have some of the features common to most projects. This kernel requires formalization. At the same time, the specificity of construction projects, reinforced by the specificity of the virtual organization of the project team, will highlight the specific features of the competence system for this type of projects. Therefore, it is necessary to propose a model of the competence system of the team to create a virtual logistics center for a construction company, while simultaneously carrying features of both universalism and specificity.

\section{The aim and objectives of research}

The aim of research is review, analysis and applying approaches to development of the system of competences of the project team for the creation of a virtual logistics center for a construction company.

To achieve this aim, it is necessary to perform the following tasks:

1. To identify the existing approaches to the creation of a system of competencies.

2. To analyze the necessary content of the elements of individual competencies for this project defined by the IPMA ICB 4.0 standard.

3. To propose a combined model for development of organizational and individual competencies in order to combine the approach of IPMA ICB 4.0 and the model of technological maturity of companies in the field of Harold Kerzner project management

\section{Research of existing solutions of the problem}

The project management methodologies have developed approaches, models and methods for forming the competence system of project teams, which can be conditionally divided into systems of organizational and personal (individual) competence. Among the first, mention should be made of the paper [1], in which a model of technological maturity of companies in the field of project management is proposed, similar to the CMMI model (Capability Maturity Model Integrated - a model of technological maturity of companies in the field of software development). The model consists of five levels (common language, common processes, unified methodology, benchmarking, continuous improvements) and transition conditions between levels (basic knowledge, process definition, process management, process improvement). The International Association for Project Management (IPMA) offers in this aspect its vision of organizational competence assessment in its OCB (Organic Competence Baseline) [2] standard, based on the IPMA Delta model. In turn, one of the main project management standards PMBOK (Project Management Body of Knowledge) [3] of the American Project Management Institute (PMI) analyzes the impact of the organization on project management. At the same time, organizational cultures and styles are singled out, formulating requirements for organizational communications, and typical organizational structures and assets of organization processes are considered. Thus, PMBOK indirectly, but determines the requirements for the formation of organizational competence. More emphasis is placed on this issue in another PMI standard, namely OPM3 (Organizational Project Management Maturity Model) [4], where the corresponding maturity model is presented.

According to individual competencies, the ICB [5] standard of the International Project Management Association is first noted, on which the bulk of the scientific development in this work will be carried out.

In addition, individual models and developments in the field of organizational competence can be found in the works of scientists [6-10], among which there is special emphasis on developments [7], in which the author presents a model of the life cycle of organizations from 9 stages, describes the «diseases» of each stages and methods of combating them. This model can be used in conjunction with the model of technological maturity of organizations.

The problem of the formation of organizational and individual competence in the project of creating a virtual logistics center for a construction company is the need to identify such models and methods of implementation that would be adequate to the specifics of this project.

\section{Methods of research}

In order to offer an adequate model of the competence system in the project of creating a virtual logistics center for a construction company, it is necessary to analyze existing models, which was done by the method of analysis of literature sources.

In order to choose the best model for imitation, a comparison method was used.

To supplement the existing model with value parameters, the method of generating ideas and the method of synthesis were applied.

To create criteria for the evaluation system for specialists of the virtual project office of the logistics company, the methods of analysis and synthesis were used.

\section{Research results}

Let's consider the necessary competences of the project team members to create a virtual logistics center of a construction company in the perspective of taxonomy of competencies, presented in the ICB 4.0 standard of the International Project Management Association IPMA. Let's analyze the necessary models and methods that team members should have for each element of competence from the three directions presented in the standard - perspective, people and practice. In addition, let's identify the values inherent in each element that a person - the professional in project management within the framework of this element - should possess (or acquire), which was not done in the standard.

\section{Perspective.}

\subsection{Strategy.}

An element of competence dedicated to testing theoretical knowledge and practical skills of constructing, analyzing and implementing a project strategy. Team members should know and be able to use models of key performance indicators, critical success factors, mission profile, vision formulation. And also own methods of benchmarking, strategic management, evaluation of strategic effectiveness. The main values of a person who possesses this element of competence are a vision of prospects, an opportunity to transfer a vision into reality. 


\subsection{Management, structures and processes.}

The knowledge and skills on integrated project management in the structure of the parent organization and in the environment of other projects are considered. A professional, judged by this element of competence, must possess models of leadership, models of integration (in particular, a project in a program or portfolio), models for describing and reengineering processes and methods of formal and informal leadership, methods of organizational transformation theory and business theories. The main values are system, sequence, orientation to the result.

1.3. Compliance, standards and regulations.

The element describes the theoretical and practical knowledge of the legal environment, as well as the systems of standardization of activities within the project. The person must have models that are included in the dissemination of standards (PMBOK, IPMA ICB, IPMA PEB, IPMA OCB, ISO 21.500, etc.), models of knowledge structuring. The methods that need to be mastered are legal regulation, benchmarking, knowledge management, standardization, dissemination of corporate ethics. The main values are legality, unification, ethics.

\subsection{Power and interest.}

Elements of the competence include project environments in the form of higher management ranks and individuals (organizations that are interested in the project), emphasis is placed on taking into account these factors in influencing the context of the project. The individual must have models of power, decision-making, influence on informal structures, as well as methods of developing organizational culture, psychological impact, identification and implementation of various types of power. The main values are discipline, harmonization of values, flexibility.

1.5. Culture and values.

The described ways of professional influence on the culture and values of the organization, as well as the socium in which the project is implemented. It is necessary the next models are the models of mission, vision, organization policy, values, corporate social responsibility. It is necessary the next methods - mission profiling, implementation of quality systems, implementation of cultural influence. The core values are «green» project management, ethics, division of corporate culture.

2. People.

2.1. Self-reflection and self-management.

The element of competence formulates the requirements for understanding one's own actions and values and the ability to take into account their influence, as well as the ability to establish and implement their own goals on a systematic basis. The person must have models of efficiency (including KPI), prioritization, methods of stress management, goal setting, personal time management. The basic values are the integrity of the person, balance, discipline.

\subsection{Personal integrity and reliability.}

Requirements are formulated for the professional's personal, «green» project management strategy, based on generally accepted moral and ethical standards. This will make it impossible to follow the numerous temptations in the project for the purpose of personal gain. Models that should be used are desired model of moral behavior, models of conflict of interest, moral and ethical norms, a model of values. Methods are «green» harmonization of values, an environmental solution to the conflict. The main values are morality, stability, decency, reliability.

\subsection{Personal communication.}

The competence element describes the interaction of the professional with the members of the project team, the staff of the parent organization and with the representatives of the stakeholders. The professional should have models of communication, feedback, presentation of information and methods of rhetoric, facial expressions, presentations, interviewing, simplification of information. The main values are conciseness, constructivism, flexibility, ingenuity.

\subsection{Attitude and interaction.}

In continuation of the previous element of competence, this element determines the requirements for establishing a stable professional relationship with representatives of the internal and external environment of the project, building a network of relationships. The necessary models are motivation, values, resistance to change. The necessary methods are stimulation, adjustment, use of «unloading», in particular through humor. The main values are stable relations, traditions, cross-culturality.

\subsection{Leadership.}

At the next stage of establishing relationships is the ability to realize leadership in the team. The person must have models of power, leadership, mentoring, coaching, and also by decision-making methods are compromise, authority, democracy, consensus, democracy (according to I. Adizes), etc. The main values are team spirit, selfcriticality, division of values, total culture.

2.6. Teamwork.

Further development of the element of relations is teamwork - productive and well-coordinated interaction of the project staff members to achieve common goals. The effectiveness of teamwork largely depends on the success of the project (program, portfolio of projects) in general. Models for use are team work, organizational structures, life cycle. Methods are polling, facilitation, recruiting, creating a favorable atmosphere. The core values are team spirit, solidarity, mutual support, professionalism.

2.7. Conflicts and crises.

To ensure the effectiveness of teamwork, it is necessary to solve ecologically the next element of competence - conflicts and crises in the project. The person should have the following models - scenarios of crises and conflicts, models of stages of conflict, models of worst scenarios. Methods for use are creativity, de-escalation, negotiation, finding a compromise, rhetoric, diplomacy. The main values are stress resistance, flexibility, professionalism, transformation of conflicts and crises into the «driving forces» of the project.

\subsection{Ingenuity.}

The element of competence determines the possibility of the professional's actions in difficult design situations in the direction of gaining from a variety of techniques and solutions of such ones, so that the situation can be managed ecologically. The main tool is the use of ingenuity and stimulating it from other team members. The professional must master the models of conceptual, convergent and divergent thinking, SWOT and PEST analysis, non-standard thinking and synergy. And the methods are strategic thinking, abstraction, scenario analysis, creativity stimulation, copying, brainstorming, benchmarking. The main values are team stability, innovation and creativity of the team.

2.9. Harmonization.

The Element of «Harmonization» competence includes the individual's ability to effectively implement processes between several parties in a project to balance interests, 
needs and expectations to achieve common consent. Includes knowledge of the models and techniques of the negotiation process (including the Chapters of negotiations), contract models (FIDIC, etc.), consent models. And methods are negotiating, identifying the desired results, establishing trust relationships. The main values are openness, empathy, confidence.

2.10. Orientation to the result.

The professional within the framework of this element of competence should guide the project team due to problems, risks, conflicts and crises, difficult situations - to achieve the goals and to obtain the product of the project of the desired quality and configuration at a specific time and within other defined limits. The professional must have models of efficiency, performance, delegation, analysis of the overall benefits. The methods necessary for a professional are the management of expectations, the integration of social, technical and environmental aspects, the definition and evaluation of alternatives. The main values are the harmonization of participants' values, the product of the project, efficiency, effectiveness, purposefulness, integrity.

3. Practice.

3.1. Design of the project.

As part of the implementation of this element of competence, a person must be able to determine the concept of project management in general, taking into account the transformation of the expectations of the customer and other stakeholders into a mechanism that increases the likelihood of achieving project success. Models for use are formalization of project lessons, success models, organization models, strategy models, leadership styles, models of project management methodologies. Methods are benchmarking, change management in the project, analysis and synthesis, structural decomposition. The main values are system, consistency, integrity, unification.

3.2. Requirements and tasks.

The professional must be able to transform the needs, expectations and strategic goals of the stakeholders into the project requirements, which in turn - in the project objectives. It is necessary to have models of expectations, facilitation, acceptance criteria for results. And methods of interviewing, identifying knowledge, synthesizing and prioritizing, formulating tasks, decomposing tasks, managing values. The main values are structural, systemic, understanding, consensus.

\subsection{Content.}

The competence element formulates the requirements for the individual in his ability to determine the boundaries of the project in terms of the configuration of the product (result) and the structure of the activity for obtaining it. Models for use are target trees, WBS structure, constraint models. Methods are definition of content, structural decomposition, planning, prioritization. The main values are structural, systematic, concreteness, compromise, flexibility.

\subsection{Time.}

A professional within the specified competence should be able to position all the elements and aspects of the project in time and achieve compliance with the timeframe. A model that uses professional calendar and network planning, a Gantt chart, critical path models, dependencies between project tasks, resource allocation. Methods are calendar-network analysis, leveling resources, optimizing the time of project implementation. The main values are timeliness, punctuality, ability to optimize.

\subsection{Organization and information.}

The element of competence determines the requirements to the person with respect to the ability to define, create and manage a temporary project organization, and also provide document circulation for it, and the integration of this workflow with the documents of the parent organization. A person must have models of organizational structures, information systems for document circulation, information security, WBS structure, responsibility matrix. And methods are recruitment, development of organizational structure, document management, information security. The main values are the adequacy of the organizational structure, the flexibility of the organizational structure, professionalism, the speed of information exchange, sufficient information completeness, information security.

\subsection{Quality}

The competency element describes the requirements for the individual regarding his ability to manage quality in the project, which in turn concerns both the quality of the product created in the project, and the quality of the management organization processes and the project management itself. Necessary models - quality management standards (TQM, ISO family standards, etc.), a model of quality indicators. Necessary methods - adaptation of the quality standard, quality testing, quality management («six sigma», lean manufacturing, kaizen), quality audit. The main values - quality, unification, adequacy of processes, informatization of management.

\subsection{Finance.}

A professional within the competence element should be able to plan the necessary financial resources, receive such resources, distribute and control their use throughout the life course of the project. The professional should have models of fundraising, budgeting (bottom-up, top-down), earned value, reservation of funds. And methods are parametric estimation, evaluation by analogy, accounting estimation, negotiation method, methods of financial control. The main values are budgetary framework, economy, optimization, expediency, development, continuity of financing.

\subsection{Resources.}

The element discloses similar content to the previous competency element, only with respect to resources that include human and material resources, technologies and innovations, infrastructures, project information, and the like. Models for use are procurement procedures in the project, monitoring and control. Methods are analysis of necessary resources, resource allocation, control of resource use, resource optimization. The main values are resource constraints, optimization, expediency, development, uninterrupted supply of resources.

\subsection{Procurement.}

The element of competence describes the processes of acquiring goods, works and services outside the executive organization. The element also includes the process of contract administration and the definition and optimization of supply chains, which is especially important for the project of creating a virtual logistics center for a construction company. The person must have models of procurement procedures, models of contract administration, models of lots, models of standard contracts. And the methods of carrying out procurement for different procedures, control over the execution of contracts, legal support, optimization of logistics chains. The main values are legality, timeliness, completeness, adequacy of the project, optimality. 


\subsection{Planning and control.}

An individual within the specified competence should be able to draw up a plan for various aspects of the project, carry out continuous monitoring of the implementation of the plan, develop and implement corrective actions in the direction of managing changes in the project. The models to use are the project life-path model, the report model in the project, the change request template. Methods are calendar-network planning, holding meetings (Scrum-meeting, start-up meeting, kick-off meeting, close-out meeting), management by exception, Earned Value, project change management. The main values are stability, flexibility, expediency, consistency of implementation.

3.11. Risks and opportunities

The competence element puts forward requirements for professionals in identifying and assessing the risks and opportunities of the project, developing a strategy for dealing with risks, mitigating measures and activities to take advantage of opportunities, monitoring triggers of risk events and the advent of the most risky events. The used models are a risk register, a risk event trigger model, risk scenarios, a SWOT analysis, a decision tree model, parameters for assessing risk events, scoring scales. The used methods are methods for identifying risks and opportunities, Monte Carlo, qualitative and quantitative assessment of risks and opportunities, sensitivity analysis, project monitoring methods (in particular Earned Value). The main values are stability of the project, flexibility of the management system, reliability, stress resistance, ingenuity, professionalism.

\subsection{Concerned parties.}

Within the framework of this element of competence, a person has the ability to identify the project stakeholders and establish long-term mutually beneficial relations with them, including strategic alliances, exchange of risks and opportunities, accounting for stakeholders' expectations, flexible adjustment of project plans. The necessary models are a register of stakeholders, response scenarios, templates of cooperation agreements, models of effective presentations, models of the negotiation process. Necessary methods are strategic management, legal support, conflict resolution, expectations management, adaptation. The core values are adaptability, understanding, harmonization of values, flexibility.

3.13. Changes and transformation.

The element of competence determines the requirements for professionals in their ability to manage changes aimed at improving the current situation, and managing transformation, aimed at creating and developing new situations and using the project's capabilities. Models that a professional must use are group dynamics, needs models (for example, the Maslow pyramid), models of motivation, models of changes. Methods that a professional must use are minimizing resistance to change, transforming it into the «driving forces» of the project, managing personal and organizational changes. The main values are development, dynamics, flexibility, adaptability, innovation.
Based on the analysis and consideration of 28 elements of competencies, let's offer a combined model for development of organizational and individual competencies that the approach of IPMA ICB 4.0 combines and the model of technological maturity of companies in the field of Harold Kerzner project management (Fig. 1). In the model of each of the levels of technological maturity, the key elements of competence (as a rule, two elements from each of the three aspects - perspective, people, practice) are aligned with the basic values inherent in the level of maturity.

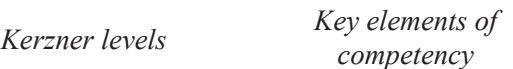

Main values

\begin{tabular}{|c|c|c|}
\hline Level 5 & $1.1,1.5$ \\
Continuous & $2.2,2.8$ \\
$3.6,3.13$ & Innovation, \\
improvement & flexibility, \\
optimization \\
\hline
\end{tabular}

\begin{tabular}{|c|c|c|}
\hline Level 4 & $1.4,1.5$ \\
$2.4,2.8$ \\
$3.5,3.11$
\end{tabular}$\quad$\begin{tabular}{c} 
Stability, \\
development, \\
quality \\
\hline
\end{tabular}

\begin{tabular}{|c|c|c|}
\hline Level 3 & $1.2,1.3$ \\
Unified & $2.5,2.6$ \\
$3.1,3.10$ & $\begin{array}{c}\text { Unification, } \\
\text { reliability, } \\
\text { efficiency }\end{array}$ \\
\hline
\end{tabular}

\begin{tabular}{|c|c|} 
Level 2 \\
Common \\
ocesses
\end{tabular}$\quad \begin{gathered}\text { Unification, } \\
2.6,2.9 \\
3.2,3.4\end{gathered} \quad \begin{gathered}\text { harmonization, } \\
\text { timeliness }\end{gathered}$

\begin{tabular}{|c|c|c|}
\hline Level 1 & $1.4,1.5$ \\
Common & $2.1-2.4$ \\
$3.3,3.8$ & $\quad$ & $\begin{array}{c}\text { Cross-culturality, } \\
\text { decency, } \\
\text { development }\end{array}$ \\
\hline
\end{tabular}

The key elements of competence and the main values of the levels of techn
maturity in the field of project management, programs and project portfolios

The use of such model in the practice of the project of creating a virtual logistics center of a construction company will allow to identify its level of technological maturity, to emphasize the main competencies in the project team, to maintain and develop the essential values inherent in the level of maturity.

According to Fig. 1 state the conditions for transitions from level to level: from the first to the second - the basic knowledge, on the other to the third - the definition of processes, from the third to the fourth - the management of processes, from the fourth to the fifth - the improvement of processes. Taking this into account, the project team can start projects to develop the technological maturity of the company taking into account the necessary priority competencies and values.

The conducted researches point to the necessity of implementing the system of evaluation of specialists of the virtual project office of the logistics company. For this assessment, it is proposed to use the known model - KPI's key performance indicators. However, filling the model should be unique for this project. Thus, to evaluate the participants in the project to create a virtual logistics center construction company will offer the following five KPIs:

1) KPI of percent of the tasks performed in full for the project period;

2) KPI of delays, ahead of time, taking into account the complex indicator of delays in accomplishing the tasks 
of the executor or advancing the implementation deadlines for a certain period of the project;

3) KPI of proposed innovations for the project period during the performance of personal tasks and formulated during the team work of the project team;

4) KPI of the received economic effect from introduction of innovations that can be expressed in monetary or time equivalent, and also in improvement of quality of products of the project;

5) KPI of solved conflicts by the project team member.

Use of these performance indicators requires prioritization between them. On this account, there are several models. The first is selection of one KPI for each individual project job. The second is using weighted convolution when each of the KPIs has equal weight, in case of using five KPIs this weight will be 0.2 for each KPI. The third model can be characterized as the most common and justified on the one hand, and causing contradictions in case of incorrect use, on the other. This is a model of weighted KPI, when using the expert group, the weight of each $\mathrm{KPI}$ in the convolution is determined for each group of project tasks (or for each task, although this significantly increases the laboriousness of the performance evaluation process). In this case, the weight will not be the same for each KPI in the convolution. For some tasks, more important KPIs will be defined, for others, others.

The results of the conducted studies allow to formulate the main tasks that the system for managing the development of the competence of the project team for the creation of a virtual logistics center for a construction company should:

- identification of the level of organizational competence;

- identification of the level of individual competence of each project team member;

- establishment of strategic benchmarks and goals for achieving the highest levels of technological maturity in the field of project management for future periods of time;

- training the team in order to master the necessary competencies;

- control of achievement of the competence level of personnel and organizational competence;

- dissemination of a culture of technological maturity development, maintenance of «fashion» for development.

\section{SWOT analysis of research results}

Strengths. The strengths of the proposed model include: - building a model of the competence system based on tested and established international standards;

- expansion of the model due to the inclusion of a value measurement in it. It correlates with the progressive value approach in modern management of projects, programs and project portfolios;

- ensuring measurability of efficiency in the model due to the introduction of a KPIs evaluation system. Weaknesses. The weaknesses of the proposed model include: - proposed KPI for improper use may be subjective, that is, include the possibility of manipulation by the manager;

- convergence of approaches is proposed without groundlessly does not include in the proposed model any developments of models formulated in the standards of the American PMI;
- introduction of the model will require additional manpower resources when transforming the existing management model.

Opportunities. The model of the competence system proposed in the study allows to:

- structure and systematize the construction and functioning of the system for assessing and improving the competence of employees of the virtual logistics center of the construction company;

- evaluate the performance of each employee of the virtual logistics center of the construction company;

- developed model with effective implementation will ensure a steady growth of organizational competence.

Threats. Transition to the proposed model of building and functioning of the system of development of organizational competence in a construction company can meet the resistance of middle managers. It can also be too time-consuming, with inefficient implementation, distract the staff more than necessary from the fulfillment of basic duties, result in delays in carrying out critical tasks, together can lead to discredit of this model and a scientific approach in general.

\section{Conclusions}

1 It is shown that there are many approaches to the development of both organizational and personal competence. The essence of the approaches is allocation of certain competencies and rank or position them in relation to a certain level of qualification or the so-called «technological maturity» in the field of project management.

2. On the basis of a combination of known approaches to maturity assessment - the taxonomy model of the individual IPMA ICB 4.0 competencies and the PMMM (Project Management Maturity Model) organizational competence model of Harold Kerzner, a combined model for the development of organizational and individual competencies is proposed. The combined model consists of 5 levels, each of which has 3 dimensions:

1) Kerzner level name;

2) key competency elements - 2 of each individual competence group for the IPMA ICB 4.0 model;

3) the main values.

3. The model is created in the development of approaches to the formalization of individual and organizational competencies and can be used in the practice of construction companies and construction logistics projects to determine the prospects and mechanisms for improving staff and organizations. The forecast increase in the efficiency of organizations due to the use of the model is $10-15 \%$.

\section{References}

1. Kerzner, H. Project Management: A Systems Approach to Planning, Scheduling, and Controlling [Text] / H. Kerzner. New Jersey: Wiley, 2009. - 1120 p.

2. IPMA Organisational Competence Baseline (IPMA OCB) for Developing Competence in Managing by Projects. Version 1.1 [Text]. - Amsterdam: International Project Management Association, 2016. - 105 p.

3. A Guide to the Project Management Body of Knowledge (PMBOK ${ }^{\circledR}$ Guide) [Text]. - Project Management Institute, 2013. - 589 p.

4. Organizational Project Management Maturity Model (OPM $\left.3^{\circledR}\right)$ [Text]. - Ed. 3. - Project Management Institute, 2013. - 246 p.

5. Individual Competence Baseline for Project, Programme \& Portfolio Management. Version 4.0 [Electronic resource]. - Zurich: 
IPMA, 2015. - Available at: \www/URL: http://products.ipma. world/ipma-product/icb/read-icb/

6. Bushuyev, S. D. Rukovodstvo po upravleniiu innovatsionnymi proektami i programmami. Vol. 1, Version 1.2 [Text] / ed. by S. D. Bushuyev. - Kyiv: Naukovii svit, 2009. - 173 p.

7. Adizes, I. How to Solve the Mismanagement Crisis: Diagnosis and Treatment of Management Problems [Text] / I. Adizes. Carpinteria: Adizes Institute, 1983. - 281 p.

8. Bushuyev, S. Harmonization models property development programmer in turbulence environment [Text] / S. Bushuyev, N. Bushueva, R. Yaroshenko // Management of Development of Complex Systems. - 2012. - No. 10. - P. 9-13.

9. Bushueva, N. S. Modeli i metody proaktivnogo upravleniia programmami organizatsionnogo razvitiia [Text]: Monograph / N. S. Bushueva. - Kyiv: Naukovii svit, 2007. - 199 p.

10. Pokolenko, V. O. Formuvannia ratsionalnoho skladu uchasnykiv vtilennia investytsiinykh proektiv [Text] / V. O. Pokolenko //

Naukovyi visnyk budivnytstva. - 2001. - No. 16. - P. 102-106

\section{АНАЛИЗ ПОДХОДОВ РАЗРАБОТКИ СИСТЕМЫ КОМПЕТЕНЦИЙ КОМАНДЫ ПРОЕКТА СОЗДАНИЯ ВИРТУАЛЬНОГО} ЛОГИСТИЧЕСКОГО ЦЕНТРА СТРОИТЕЛЬНОЙ КОМПАНИИ

Поставлена задача развития компетентности проекта создания виртуального логистического центра строительной ком- пании. Исследуются подходы к идентификации и развитию индивидуальной и организационной компетентности. Для проекта рассмотрено наполнение 28-и компетенций согласно модели Международной ассоциации управления проектами. Предложена комбинированная модель развития организационноиндивидуальных компетенций.

Ключевые слова: управление проектами, строительная логистика, компетентность проекта, организационно-индивидуальные компетенции.

Antypenko Yevgen, Doctor of Technical Sciences, Professor, Department of Construction Production and Project Management, Zaporizhzhya National Technical University, Ukraine, e-mail: bud.zntu@gmail.com, ORCID: https://orcid.org/0000-0001-8048-0144

Ivko Andrii, Postgraduate Student, Department of Construction Production and Project Management, Zaporizhzhya National Technical University, Ukraine, e-mail: Aspirant80@i.ua, ORCID: https:// orcid.org/0000-0002-2361-1192

\section{Stanovska I., Heblov I., Guriev I., Koshuljan $\mathbf{5}$.}

\section{DEVELOPMENT OF THE STRUCTURE AND CONTENT OF SCRUM-TECHNOLOGIES OF CONTROL OF FAST-FLOWING MEDICAL PROJECTS WITH CRITICAL RISKS}

Показано, що після перерозподілу ролей учасників медичного проекту, пов'язаного з тим, що продукт проекту - життя людини - безцінний, а проект знаходиться у виключній зоні ризику, з'являється можливість використовувати SCRUM-технологї в управлінні проектом хірургічної операції. Запропоновано систему оптимізації процесу прийняття проектних рішень в медицині. Система випробувана в хірургічній практичі з позитивним ефектом.

Ключові слова: SCRUM-технологї, учасники проекту, планування Спринтів, швидкоплинні медичні проекти, критичні ризики.

\section{Introduction}

SCRUM-technologies first appeared in the IT field, mainly in the implementation of projects to create computer programs. But there are other projects in which SCRUM-technologies are almost the only way to achieve the desired goal.

SCRUM project management technologies are most often used when the project has the following properties:

- it has orders of magnitude shorter than «normal» projects;

- the project team is much less structured: everyone can do everything and can be involved in the implementation of any stage of the project;

- the project manager is located inside such Team and works at the level of other Team members;

- the stages of project implementation, which are called Sprints in SCRUM-technologies, are refined after the completion of the previous stage, with the definition of the quality of their implementation and with an eye on the achievement of the mission and the objectives of the project as a whole.

In some cases, these factors are supplemented by a high risk hazard that accompanies the project. At the same time, both risk factors - the likelihood of occurrence and the cost of risk losses - are at a very high level. In the work such projects were called «fast flowing with increased risk hazard and strict responsibility for the results of their implementation». The most prominent representatives of such projects are medical, in particular, surgical operations.

The urgency of work in this direction is also determined by the fact that surgical operations are constantly becoming more complicated due to the use of modern instruments and instruments, which are becoming increasingly difficult to manage without modern information technologies 